\title{
AKTIVITAS ANTIBAKTERI EKSTRAK METANOL Acalypha hispida TERHADAP BAKTERI Shigella flexneri DAN Bacillus cereus IHB B 379
}

\author{
(Antibacterial activity of Acalypha hispida flower methanol extract against to Shigella flexneri \\ and Bacillus cereus IHB B 379 bactery)
}

\author{
Elvi Rusmiyanto Pancaning Wardoyo ${ }^{1 *}$, Devinda Ekarizky Diputri ${ }^{1)}$, Rikhsan \\ Kurniatuhadi ${ }^{1)}$ \\ ${ }^{1}$ Program Studi Biologi, Fakultas MIPA, Universitas Tanjungpura, Jl. Prof. Dr. H. Hadari Nawawi, \\ Pontianak, Indonesia \\ *e-mail korespondensi: elvi.rusmiyanto@fmipa.untan.ac.id
}

\begin{abstract}
Acalypha hispida (ekor kucing) is one of the traditional medicinal plants that has been used by people for generations to treat diarrhea and cancer. The purpose of this study was to determine the antibacterial activity and effective concentration of $\mathrm{A}$. hispida flower methanol extract against Shigella flexneri and Bacillus cereus bacteria. The research sample used was A. hispida flowers obtained from Pontianak City. The solvent used is methanol. Antibacterial activity test uses the disk diffusion method (Kirby-Bauer) with 5 levels of methanol extract concentration of A. hispida flowers on S. flexneri bacteria, which is 1.2, 1.3, 1.4, 1.5 and $1.6 \mathrm{~g} / \mathrm{ml}$ and B. cereus IHB B 379 for 0.75; 0.80; 0.85; 0.90; and $0.95 \mathrm{~g} / \mathrm{mL}$. The negative control used $10 \%$ DMSO solution and the positive control used ciprofloaxin as a comparison. The results showed that the concentration of methanol extract of $\mathrm{A}$. hispida flowers which effectively inhibited the growth of S. flexneri and B. cereus bacteria was $1.2 \mathrm{~g} / \mathrm{mL}$ and $0.75 \mathrm{~g} / \mathrm{mL}$. The methanol extract of A. hispida flower contains compounds of alkaloids, flavonoids, tannins, phenols, steroids and terpenoids
\end{abstract}

Keywords: Acalypha hispida, antibacterial, Shigella flexneri, Bacillus cereus

\section{Abstrak}

Acalypha hispida (ekor kucing) adalah salah satu tanaman obat tradisional yang sudah dimanfaatkan masyarakat secara turun temurun untuk mengobati diare dan kanker. Tujuan penelitian ini adalah untuk mengetahui aktivitas antibakteri dan konsentrasi efektif ekstrak metanol bunga A. hispida terhadap bakteri Shigella flexneri dan Bacillus cereus. Sampel penelitian yang digunakan adalah bunga A. hispida yang diperoleh dari Kota Pontianak. Pelarut yang digunakan adalah methanol. Uji aktivitas antibakteri menggunakan metode difusi cakram (Kirby-Bauer) dengan perlakuan 5 taraf konsentrasi ekstrak methanol bunga A. hispida pada bakteri S. Flexneri, yaitu 1,2; 1,3; 1,4; 1,5; dan 1,6 g/ml serta pada bakteri B. cereus sebesar 0,75;0,80;0,85; 0,90; dan 0,95 g/mL. Kontrol negatif menggunakan larutan DMSO $10 \%$ dan control positif menggunakan senyawa ciprofloaxin sebagai pembanding. Hasil penelitian menunjukkan bahwa konsentrasi ekstrak methanol bunga A. hispida yang menghambat secara efektif pertumbuhan bakteri S. flexneri dan B. cereus sebesar $1,2 \mathrm{~g} / \mathrm{mL}$ dan $0,75 \mathrm{~g} / \mathrm{mL}$. Ekstrak methanol bunga A. hispida mengandung senyawa golongan alkaloid, flavonoid, tannin, fenol, steroid dan terpenoid.

Kata kunci: Acalypha hispida, antibakteri, Shigella flexneri, Bacillus cereus 


\section{PENDAHULUAN}

Masyarakat di Indonesia telah menggunakan pengobatan tradisional dengan cara memanfaatkan beberapa jenis tumbuhan untuk mengatasi masalah kesehatan, seperti meningkatkan daya tahan tubuh dan menyembuhkan penyakit (Kasenda et al., 2016). Salah satu organisme penyebab penyakit yang banyak diderita oleh masyarakat adalah bakteri, seperti Shigella flexneri dan Bacillus cereus yang menyebabkan muntah-muntah dan diare.

Sampai saat ini, masyarakat cenderung melakukan pengobatan secara medis dengan menggunakan obat antibiotik untuk menyembuhkan penyakit yang disebabkan oleh bakteri. Selain harganya yang tinggi dan dapat menimbulkan efek samping yang tidak diinginkan, penggunaan obat antibiotik yang tidak tepat dan secara terus menerus dapat menyebabkan bakteri menjadi resistensi bakteri. Oleh karena itu, perlu dilakukan usaha untuk mencari alternatif pengobatan yang memiliki efek samping yang kecil harganya terjangkau masyarakat. Salah satu alternatif yang digunakan adalah dengan memanfaatkan tumbuhan sebagai bahan pengobatan tradisional sebagai alternatif pengganti obat antibiotik (Moningka et al., 2015).

Salah satu jenis tumbuhan yang diketahui memiliki khasiat sebagai obat dan dapat digunakan untuk mengobati penyakit yang disebabkan oleh bakteri adalah tumbuhan A. hispida. Tumbuhan A. hispida termasuk famili
Euphorbiaceae dan dikenal masyarakat sebagai tumbuhan ekor kucing. Tumbuhan A. hispida merupakan tumbuhan yang sudah dimanfaatkan masyarakat sejak dulu untuk mengobati penyakit antara lain bercak putih dikulit (vitiligo), batuk darah, sariawan, disentri, dan mimisan. Tumbuhan $A$. hispida juga diketahui memiliki aktvitas sebagai antioksidan (Noumedem et al., 2013), antimikrobia (Adesina et al., 2000), diare (Manikanta et el., 2014), dan bersifat sitotoksik (Bokshi et al., 2012).

Berdasarkan penelitian Moningka tet al. (2015), daun A. hispida dapat menghambat bakteri Staphylococcus aureus dan Escherichia coli pada konsentrasi sebesar $0,02 \mathrm{~g} / \mathrm{mL}$ dan 0,04 $\mathrm{g} / \mathrm{mL}$. Menurut Bokshi et al. (2012) ekstrak etanol daun A. hispida menunjukkan aktivitas terhadap pertumbuhan bakteri Salmonella typhe, Enterococcus coli, Streptococcus saprophyticus, Streptococcus agalactin dan Shigella disentri. Tumbuhan A. hispida mengandung beberapa senyawa kimia antara lain saponin, tanin, flavonoid, steroid (Bokshi et al., 2012; Manikanta et el., 2014; Rahayu et al., 2012) dan minyak atsiri (Aboaba \& Omotoso, 2012).

Penelitian yang telah dilakukan oleh Noumedem et al. (2013) menunjukkan bahwa ekstrak methanol daun A. manniana mengandung alkaloid, tanin, antosianin, flavonoid, fenol dan steroid. Menurut Aboaba \& Omotoso (2012), minyak esensial daun A. hispida dan A. wilkesiana terdiri atas 
neral $(11,04 \%)$, citral $(12,87 \%)$, 6,10,14, trimethyl-2-pentadecanone $(13,43 \%)$ dan n-hexadecanoic, acid $(14,69 \%)$. Senyawa yang berpotensi memiliki aktivitas antimikroba telah diisolasi dari ekstrak etanol daun $A$. wilkesiana dan $A$. hispida adalah senyawa asam galat, corilagin dan geraniin, quercetin 3-O-rutinoside dan kaempferol 3-O-rutinoside (Adesina et al., 2000).

Kumoro (2015) menyatakan bahwa senyawa metabolit sekunder yang terkandung pada tumbuhan, seperti saponin, flavanoid, tanin, dan minyak atsiri memiliki aktivitas biologi tertentu sehingga berpotensi untuk dikembangkan sebagai obat herbal. Berdasarkan hal tersebut diatas, maka penelitan yang mengkaji aktivitas biologi ekstrak metanol A. hispida terhadap bakteri Shigella flexneri dan Bacillus cereus perlu untuk dilakukan. Penelitian ini bertujuan untuk mengetahui aktivitas antibakteri dan menentukan konsentrasi efektif ekstrak metanol bunga $A$. hispida terhadap bakteri $S$. flexneri dan B. cereus.

\section{METODE PENELITIAN}

\section{Waktu dan Tempat Penelitian}

Penelitian dilakukan selama 4 bulan yang dimulai pada bulan September sampai Desember 2019. Preparasi ekstrak bunga sampel dan uji fitokimia dilakukan di Laboratorium Biologi. Uji aktivtas antibakteri dilakukan di Laboratorium Mikrobiologi, Jurusan Biologi Fakultas MIPA Universitas Tanjungpura Pontianak, sedangkan vakum evaporasi ekstrak metanol dilakukan di Laboratorium Rekayasa, Politeknik Negeri Pontianak.

\section{Alat dan Bahan}

Alat yang digunakan adalah petridsh (Iwaki), blender (National), autoklaf (Memmert), vortex (Biorad), laminar air flow (Esco), inkubator (Memmert), jangka sorong dan vacum rotary evaporator (Buchi). Sedangkan bahan yang digunakan adalah alkohol 70\%, akuades, antibiotik ciprofloxacin 500 mg, Bunga A. hispida, biakan bakteri S. flexneri dan B. cereus IHB B 379, Dimethyl Sulfoxsida (DMSO) 10\%, metanol p.a (Merck), Mueller Hinton Agar (MHA), Nutrient Agar (NA), larutan Mc Farland 0,5.

\section{Prosedur Kerja}

\section{Pembuatan Simplisia}

Sampel bunga A. hispida diambil dan dikumpulkan sebanyak $3 \mathrm{~kg}$, dilanjtkan dengan dibersihkan menggunakan air mengalir kemudian dikeringkananginkan (Kumoro, 2015). Sampel yang telah kering dibuat menjadi serbuk dengan menggunakan blender.

\section{Pembuatan Ekstrak Bunga A. hispida}

Pembuatan ekstrak dilakukan dengan menggunakan metode maserasi. Seberat $100 \mathrm{~g}$ simplisia direndam dalam larutan methanol $1000 \mathrm{ml}$ (Wardoyo et al., 2014). Perendaman dilakukan selama 3x24 jam dan dilakukan pengadukan setiap 1x24 jam. Setelah perendaman, maserat diambil dengan cara disaring, kemudian maserat hasil penyaringan dipekatkan menggunakan vacum rotary evaporator pada kecepatan 70-110 rpm dan suhu 40- 
$45^{\circ} \mathrm{C}$, sehingga diperoleh ekstrak kental. Ekstrak kental disimpan dalam wadah steril kemudian dibungkus dengan aluminium foil.

\section{Peremajaan Kultur Murni Bakteri}

Peremajaan dari isolat bakteri $S$. flexneri dan B. cereus IHB 379 dilakukan dengan menginokulasikan sebanyak 1 ose pada media agar miring NA (Nutrient Agar) di dalam tabung reaksi dengan cara menggoreskan secara aseptik pada permukaan agar. Selanjutnya diinkubasi selama 24 jam pada suhu $37^{\circ} \mathrm{C}$ (Heryati et al., 2016)

\section{Pembuatan Larutan Konsentrasi}

Perlakuan konsentrasi ekstrak methanol bunga $A$. hispida dibuat dalam 5 taraf konsentrasi sebesar 1,2; 1,3; 1,4; 1,5, dan 1,6 g/mL untuk $S$. flexneri dan konsentrasi sebesar 0,$75 ; 0,80 ; 0,85$; 0,90; dan 0, 95, g.mL untuk B. cereus. Setelah ditambahkan DMSO $10 \%$ sebanyak $1 \mathrm{ml}$ larutan digojog menggunakan vortex sampai larut. Kontrol positif menggunakan antibiotik ciprofloxacin, sedangkan kontrol negatif menggunakan larutan DMSO 10\%.

Persiapan Inokulum Bakteri S. flexneri

dan B. cereus

Isolat kultur bakteri $S$. flexneri dan B. cereus IHB B 397 yang telah dibuat diambil menggunakan jarum ose kemudian dimasukkan ke dalam $9 \mathrm{~mL}$ akuades steril sampai kekeruhan inokulum sama dengan kekeruhan larutan standar Mc Farland 0,5 (Sutton, 2011).

\section{Uji Aktivitas Antibakteri}

Pengujian aktivitas ekstak methanol bunga $A$. hispida dilakukan dengan cara difusi cakram (KirbyBauer) dengan mengunakan teknik apus (Heryati et al., 2016). Media agar MHA (Mueller Hinton Agar) yang telah dibuat dituang sebanyak $20 \mathrm{~mL}$ ke dalam masing-masing cawan petri dan dibiarkan media hingga memadat. Setelah media memadat diambil suspensi bakteri kemudian diapus di atas permukaan agar.

Kertas cakram yang telah disterilkan direndam ke dalam ekstrak methanol bunga $A$. hispida pada masing-masing botol vial sesuai konsentrasi perlakuan selama \pm 30 menit (Dewi, 2010). Kertas cakram diangkat dari botol vial menggunakan pinset kemudian diletakkan di atas media agar. Masing-masing media agar diletakkan 4 ulangan ekstrak metanol $A$. hispida untuk setiap konsentrasi perlakuan. Cara yang sama juga dilakukan terhadap kontrol positif dan kontrol negatif. Kemudian masingmasing cawan petri diinkubasi pada waktu 24 jam dan 48 jam dalam suhu $37^{\circ} \mathrm{C}$ (Moningka et al., 2015).

Uji Fitokimia

1. Uji Alkaloid

Sebanyak $1 \mathrm{~mL}$ ekstrak ditambahkan beberapa tetes asam klorid ( $\mathrm{HCl})$ 1\%. Kemudian ditambahkan enam tetes reagen Wagner. Adanya alkaloid ditandai dengan terbentuknya endapan berwarna coklat (kemerahan) (Harborne, 2006).

2. Uji Flavanoid

Sebanyak $1 \mathrm{~mL}$ ekstrak ditambahkan dengan beberapa tetes larutan $\mathrm{NaOH}$. Terbentuknya warna 
kuning menujukkan adanya kandungan flavanoid (Roopashree et al., 2008).

3. Uji Saponin

Sebanyak $1 \mathrm{~mL}$ ekstrak ditambahkan $1 \mathrm{~mL}$ etanol. Selanjutnya ditambahkan beberapa tetes akuades dan di kocok kuat selama beberapa menit. Adanya kandungan saponin ditandai dengan terbentuknya busa yang stabil setinggi $\pm 1 \mathrm{~cm}$ selama kurang lebih 20 menit (Roopashree et al., 2008).

\section{Uji Tanin}

Sebanyak $1 \mathrm{~mL}$ ekstrak ditambahkan ke dalam $2 \mathrm{~mL}$ akuades. Kemudian di tambahkan dua atau tiga tetes larutas $\mathrm{FeCl}_{3} 1 \%$. Terbentuknya warna biru-kehitaman maka ekstrak tersebut mengandung senyawa tanin (Harborne, 2006).

5. Uji Fenol

Sebanyak $1 \mathrm{~mL}$ ekstrak dua tetes larutan $\mathrm{FeCl}_{3}$. Pembentukan warna hijau atau hijau biru menujukkan adanya kandungan fenol (Harborne, 2006).

6. Uji Steroid

Ekstra ditambahkan dengah beberapa tetes asam asetat, kemudian didihkan dan didinginkan. Setelah itu, ditambahkan asam sulfat pekat. Terbentuknya warna merah kecoklatan menunjukkan adanya steroid (Abbas et al., 2012).

7. Uji Terpenoid

Sebanyak $1 \mathrm{~mL}$ ekstrak tumbuhan ditambahkan beberapa tetes asam sulfat hingga terbentuk lapisan. Terbentuknya warna coklat kemerahan pada batas antar lapisan, maka ekstrak tersebut mengandung terpenoid (Abbas et al.,
2012).

\section{Analisis dan Penyajian Data}

Analisis data dilakukan dengan menggunakan aplikasi SPSS versi 18 . Data diameter zona hambat pada setiap perlakuan dianalisis dengan menggunakan analisi variansi (Anova) dan jika menunjukkan beda nyata akan dilanjutkan dengan uji Duncan Multiple Range Test (DMRT) (Sugiyono, 2018).

\section{HASIL DAN PEMBAHASAN}

Hasil

Hasil uji DMRT perlakuan konsentrasi ekstrak methanol A. hispida terhadap pertumbuhan $S$. flexneri menunjukan tidak berbeda nyata antar perlakuan untuk masa inkubasi 24 jam $\left(\mathrm{F}_{6.21}=298,302, \quad \mathrm{p}=0,000\right), \quad$ namun menunjukkan hasil yang berbeda nyata antar perlakuan pada masa inkubasi 48 jam $\left(\mathrm{F}_{6 \cdot 21}=611,060, \mathrm{p}=0,000\right)$ (Tabel. 1)

Berdasarkan Tabel 2, hasil uji DMRT perlakuan konsentrasi ekstrak methanol A. hispida terhadap pertumbuhan $B$. cereus menunjukkan tidak berbeda nyata antar perlakuan untuk masa inkubasi 24 jam $\left(\mathrm{F}_{6.21}=\right.$ 1050, 558, $\mathrm{p}=0,000)$, namun menunjukkan hasil yang berbeda nyata antar perlakuan pada masa inkubasi 48 jam $\left(\mathrm{F}_{6 \cdot 21}=1093,927, \mathrm{p}=0,000\right)$.

Hasil uji fitokimia menunjukkan bahwa ekstrak methanol bunga $A$. hispida mengandung senyawa metabolit sekunder golongan alkaloid, flavonoid, tanin, fenol, steroid dan terpenoid (Tabel. 3). 
Tabel 1. Rerata diameter zona hambat $S$. flexneri dengan pemberian konsentrasi ekstrak metanol bunga $A$. hispida yang berbeda

\begin{tabular}{cccc}
\hline \multirow{2}{*}{$\begin{array}{c}\text { Konsentrasi } \\
(\mathbf{g} / \mathbf{m L})\end{array}$} & \multicolumn{2}{c}{ Rerata Diameter $(\mathbf{m m})$} & \multirow{2}{*}{ Kategori } \\
\cline { 2 - 3 } & Inkubasi 24 jam & Inkubasi 48 jam & \\
\hline DMSO 10\% (K-) & $0,00 \pm 0,00^{\mathrm{a}}$ & $0,00 \pm 0,00^{\mathrm{a}}$ & - \\
1,2 & $16,26 \pm 2,06^{\mathrm{b}}$ & $16,29 \pm 1,04^{\mathrm{b}}$ & Kuat \\
1,3 & $16,81 \pm 1,04^{\mathrm{b}}$ & $16,85 \pm 0,74^{\mathrm{bc}}$ & Kuat \\
1,4 & $16,92 \pm 0,74^{\mathrm{b}}$ & $16,95 \pm 0,84^{\mathrm{bcd}}$ & Kuat \\
1,5 & $17,64 \pm 0,84^{\mathrm{b}}$ & $17,67 \pm 0,68^{\mathrm{cd}}$ & Kuat \\
1,6 & $17,83 \pm 0,68^{\mathrm{b}}$ & $18,08 \pm 0,49^{\mathrm{d}}$ & Kuat \\
Ciprofloxacin $(\mathrm{K}+)$ & $29,84 \pm 2,06^{\mathrm{c}}$ & $31,66 \pm 0,88^{\mathrm{e}}$ & Sangat Kuat
\end{tabular}

Keterangan tabel: angka pada kolom yang sama dan diikuti oleh huruf yang sama menunjukkan hasil yang tidak berbeda nyata pada taraf $95 \%$ menurut uji Duncan.

$(\mathrm{K}-)$ = kontrol negatif, $\mathrm{K}(+)=$ kontrol positif, (-) tidak terdeteksi

Tabel 2. Rerata diameter zona hambat $B$. cereus dengan pemberian konsentrasi ekstrak metanol bunga $A$. hispida yang berbeda

\begin{tabular}{cccc}
\hline \multirow{2}{*}{ Konsentrasi (g/mL) } & \multicolumn{2}{c}{ Rerata Diameter $(\mathbf{m m})$} & \multirow{2}{*}{ Kategori } \\
\cline { 2 - 3 } DMSO $10 \%(\mathrm{~K}-)$ & Inkubasi 24 jam & Inkubasi 48 jam & - \\
0,75 & $0,00 \pm 0,00^{\mathrm{a}}$ & $0,00 \pm 0,00^{\mathrm{a}}$ & Kuat \\
0,80 & $18,20 \pm 0,28^{\mathrm{b}}$ & $18,92 \pm 0,5^{\mathrm{b}}$ & Kuat \\
0,85 & $18,60 \pm 0,49^{\mathrm{b}}$ & $19,15 \pm 0,88^{\mathrm{b}}$ & Kuat \\
0,90 & $18,79 \pm 0,54^{\mathrm{b}}$ & $19,31 \pm 0,59^{\mathrm{bc}}$ & Kuat \\
0,95 & $18,88 \pm 0,75^{\mathrm{b}}$ & $19,61 \pm 0,19^{\mathrm{bc}}$ & Sangat Kuat \\
Ciprofloxacin $(\mathrm{K}+)$ & $18,89 \pm 0,78^{\mathrm{b}}$ & $20,08 \pm 0,57^{\mathrm{c}}$ & Sangat Kuat \\
\hline
\end{tabular}

Keterangan tabel: angka pada kolom yang sama dan diikuti oleh huruf yang sama menunjukkan hasil yang tidak berbeda nyata pada taraf $95 \%$ menurut uji Duncan.

$(\mathrm{K}-)$ = kontrol negatif, $\mathrm{K}(+)=$ kontrol positif, (-) tidak terdeteksi
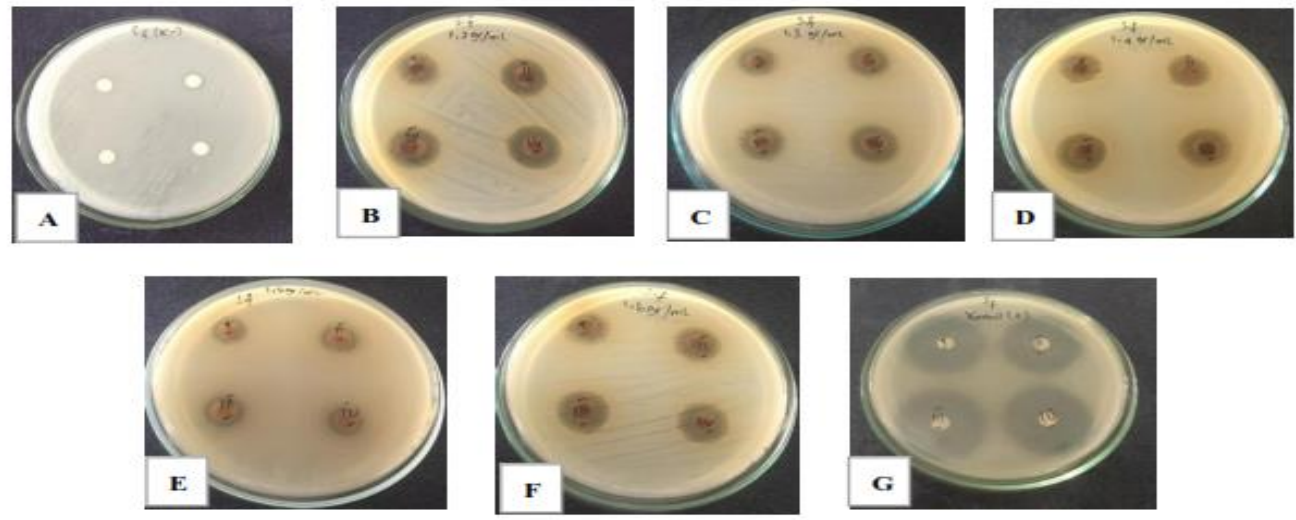

Gambar 1. Zona hambat yang terbentuk pada S. flexneri setelah pemberian ekstrak methanol bunga $A$. hispida setelah inkubasi 48 jam.

Keterangan: Kontrol negatif (A), Konsentrasi $1,2 \mathrm{~g} / \mathrm{mL}$ (B), Konsentrasi 1,3 g/mL (C), Konsentrasi 1,4 g/mL (D), Konsentrasi 1,5 $\mathrm{g} / \mathrm{mL}$ (E), Konsentrasi 1,6 g/mL (F), Kontrol positif (G) 

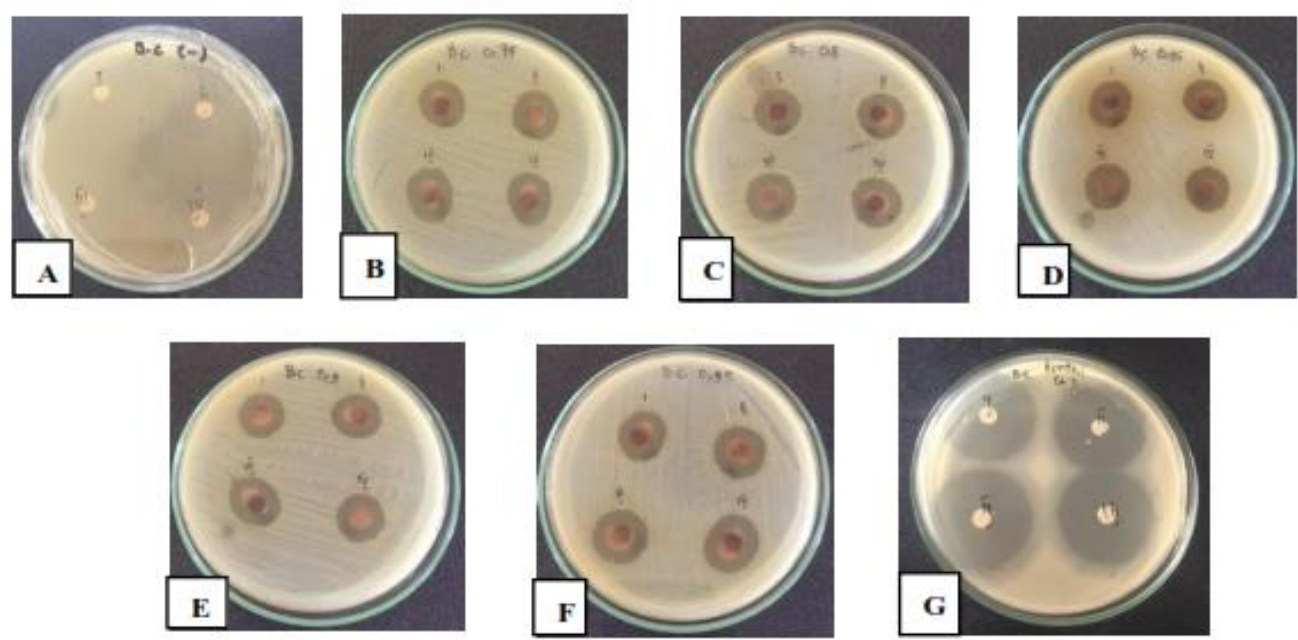

Gambar 2. Zona hambat yang terbentuk pada B. cereus setelah pemberian ekstrak methanol bunga A. hispida setelah nkubasi 48 jam. Kontrol negatif (A), Konsentrasi 0,75 g/mL (B), Konsentrasi 0,80 g/mL (C), Konsentrasi 0,85 $\mathrm{g} / \mathrm{mL}$ (D), Konsentrasi $0,90 \mathrm{~g} / \mathrm{mL}$ (E), Konsentrasi $0,95 \mathrm{~g} / \mathrm{mL}$ (F), Kontrol positif (G)

Tabel. 3 Hasil uji fitokimia ekstrak metanol bunga A. hispida

\begin{tabular}{cccc}
\hline No. & Metabolit sekunder & Pereaksi & Hasil \\
\hline 1 & Alkaloid & Wagner & + \\
2 & Flavonoid & NaOH & + \\
3 & Saponin & Etanol \& akuades & - \\
4 & Tanin & $\mathrm{FeCl}_{3}$ & + \\
5 & Fenol & Etanol & + \\
6 & Steroid & Asam asetat \& Asam sulfat & + \\
7 & Terpenoid & Asam sulfat & + \\
\hline
\end{tabular}

Keterangan tabel: $(+)=$ kadar rendah, $(++)=$ kadar sedang, $(+++)=$ kadar tinggi, $(-)$ tidak terdeteksi

\section{Pembahasan}

Uji aktivitas antibakteri dilakukan selama 24 dan 48 jam dilakukan untuk mengetahui sifat bakteriostatik dan baktriosida ekstrak methanol bunga $A$. hispida terhadap pertumbuhan bakteri $S$. flexneri dan B. cereus. Berdasarkan tabel 1 dapat dilihat bahwa perbedaan waktu inkubasi 24 dan 48 jam terhadap peningkatan diameter zona hambat pertumbuhan bakteri $S$. flexneri secara nyata terjadi pada konsentrasi $1,6 \mathrm{~g} / \mathrm{mL}$ dan kontrol positif. Demikian juga untuk
Tabel 2, menunjukkan bahwa perbedaan waktu inkubasi 24 dan 48 jam terhadap peningkatan zona hambat pertumbuhan bakteri $B$. cereus secara nyata terjadi pada konsentrasi $0,95 \mathrm{~g} / \mathrm{mL}$ dan kontrol positif. Pengujian aktivitas antibakteri selama inkubasi 24 jam disebabkan pada saat 24 jam bakteri masih berada pada fase log. Penghambatan pertumbuhan bakteri yang diujikan pada fase log menunjukkan sensitivitas yang lebih optimal dibandingkan fase lag dan fase stasioner. Kondisi ini dikarenakan saat fase log laju 
metabolisme pada bakteri sangat tinggi dan berlangsung dalam kondisi tidak stabil. Pada saat seperti ini, bakteri akan lebih peka terhadap senyawa kimia dan antibiotik.

Pengamatan aktivitas antibakteri selama masa inkubasi 48 jam mengalami penambahan zona hambat. Penambahan zona hambat menunjukkan bahwa ekstrak metanol bunga A. hispida bersifat bakteriosida. Senyawa yang memiliki sifat bakteriosida berkerja membunuh bakteri (Aini et al., 2017). Kontrol positif dengan ciprofloaxin pada inkubasi 48 jam mengalami penambahan zona hambat. Hal ini menyatakan bahwa ciprofloxacin sebagai kontrol positif bersifat bakteriosida terhadap bakteri S. flexneri dan B. cereus.

Berdasarkan hasil uji DMRT diketahui bahwa konsentrasi 1,6 g/mL dari ekstrak methanol bunga $A$. hispida memiliki zona hambat terbesar $1,2 \mathrm{~g} / \mathrm{mL}$ pada bakteri $S$. flexneri (Tabel. 1) dan konsentrasi $0,90 \mathrm{~g} / \mathrm{mL}$ pada bakteri $B$. cereus dengan respon hambatan sangat kuat (Tabel. 2). Perlakuan pada ekstrak metanol bunga $A$. hispida menunjukkan bahwa semakin tinggi konsentrasi ekstrak, maka semakin besar diameter daya hambat yang terbentuk. Menurut Syaifuddin et al (2018), perbedaan besar zona daya hambat suatu bakteri ditentukan dari kadar konsentrasi ekstrak yang digunakan. Perbedaan kadar kandungan senyawa antimikroba dalam suatu konsentarasi ekstrak mempengaruhi zona hambat yang terbentuk. Semakin besar konsentrasi yang digunakan, semakin besar pula kadar antimikroba di dalamnya, maka semakin besar zona hambat yang dihasilkan
(Cowan, 1999).

Kontrol positif bakteri $S$. flexneri dan B. Cereus menunjukkan hasil berbeda nyata pada semua ekstrak yang digunakan (Tabel 1 dan Tabel 2). Kontrol positif merupakan uji pembanding yang menghasilkan zona hambat terbesar. Hal ini dikarenakan ciprofloxacin memiliki bersifat bakteriosidal dengan spektrum luas terhadap bakteri gram-positif maupun negatif. Mekanisme kerja ciprofloxacin adalah menghambat aktivitas DNA-gyrase bakteri dan perubahan permeabilitas membran (Irene \& Hatta, 2009).

Pembentukan zona hambat pada ekstrak methanol bunga $A$. hispida juga dipengaruhi oleh bakteri uji yang digunakan. Perbedaan ini disebabkan dari susunan dinding sel bakteri gram negatif dan positif yang tidak sama. Bakteri $S$. flexneri merupakan bakteri gram negatif yang memiliki sistem seleksi terhadap zatzat asing yaitu pada lapisan lipopolisakarida. Struktur dinding sel bakteri gram negatif relatif lebih kompleks, berlapis tiga yaitu lapisan luar yang berupa lipoprotein, lapisan tengah yang berupa lipopolisakarida, lapisan dalam berupa peptidoglikan, dan terdapat porin yang terbentuk dari protein (Allison \& Gilbert, 2004). Struktur yang lebih kompleks mengakibatkan dinding sel bakteri gram negatif lebih sulit untuk dilalui senyawa antimikroba.

Bakteri B. cereus IHB B 379 merupakan bakteri gram positif yang memiliki susunan dinding sel lebih sederhana. Dinding sel bakteri gram positif banyak mengandung teikoat dan asam teikoronat serta molekul polisakarida, 
sehingga memudahkan senyawa antimikroba untuk masuk ke dalam sel dan menemukan sasaran untuk bekerja (Allison \& Gilbert, 2004). Penghambatan terhadap pertumbuhan koloni mikroba diduga disebabkan karena kerusakan yang terjadi pada komponen struktural membran sel mikroba. Membran sel yang tersusun atas protein dan lipid sangat rentan terhadap zat kimia yang menurunkan tegangan permukaan. Kerusakan membran sel menyebabkan terganggunya transport nutrisi melalui membran sel sehingga sel mikroba mengalami kekurangan nutrisi yang diperlukan bagi pertumbuhannya (Allison $\&$ Gilbert, 2004).

Berdasarkan hasil uji fitokimia ekstrak methanol bunga A. hispida menunjukkan bahwa metabolit yang terkandung adalah alkaloid, flavanoid, tanin, fenol, steroid, dan terpenoid. Menurut Manikanta et al. (2014), tumbuhan A. hispida memiliki senyawa yang memiliki aktivitas sebagai antibakteri, antara lain alkaloid dan flavonoid. Penelitian yang dilakukan oleh Moningka et al. (2015) menyatakan bahwa senyawa kimia seperti tanin, saponin, minyak atsiri, flavonoid, acalyphin dapat menghambat bakteri Staphylococcus aureus dan Eschericia coli dengan konsentrasi hambat minimum sebesar $0,02 \mathrm{~g} / \mathrm{mL}$ dan $0,04 \mathrm{~g} / \mathrm{mL}$ yang termasuk kategori respon hambatan kuat.

Senyawa alkaloid memiliki gugus basa yang mengandung nitrogen akan bereaksi dengan senyawa asam amino yang menyusun dinding sel bakteri dan DNA bakteri. Flavonoid bersifat polar sehingga lebih mudah menembus lapisan peptidoglikan yang juga bersifat polar pada bakteri gram positif, sehingga fungsi normalnya menonaktifkan enzim dan merusak dinding sel serta membran sel bakteri. Tanin merupakan senyawa organik komplek yang berperan sebagai antimikrobial. Adanya tanin sebagai antibakteri akan mengganggu sintesa peptidoglikan sehingga pembentukan dinding sel menjadi kurang sempurna.

Penghambatan pertumbuhan sel mikroba oleh senyawa fenol disebabkan kemampuan fenol untuk mendenaturasi protein dan merusak membran sel dengan cara melarutkan lemak yang terdapat pada dinding sel. Senyawa golongan steroid dan terpenoid dapat bereaksi dengan porin (protein transmembran) pada membran luar dinding sel bakteri, membentuk ikatan polimer yang kuat dan merusak porin serta mengurangi permeabilitas dinding sel bakteri, yang berakibat sel bakteri kekurangan nutrisi dan pertumbuhan bakteri terhambat atau mati (Aini et al., 2015).

\section{KESIMPULAN}

Semakin besar konsentrasi ekstrak methanol bunga $A$. hispida yang diberikan, semakin besar zona hambat pertumbuhan bakteri S. flexneri dan B. cereus IHB B 379. Konsentrasi efektif ekstrak metanol bunga $A$. hispida dalam menghambat pertumbuhan bakteri S. flexneri sebesar 1,2 $\mathrm{g} / \mathrm{mL}$ dengan kategori respon hambatan kuat dan bakteri B. cereus IHB B 379 sebesar $0,75 \mathrm{~g} / \mathrm{mL}$ dengan kategori respon hambatan sangat kuat.

\section{DAFTAR PUSTAKA}

Aboaba, S., \& Omotoso, O. (2012). Chemical constituents, toxicity and 
larvicidal activity of the essential oil from the leaves of Acalypha hispida and Acalypha wilkesiana in southwest Nigeria. Elixir Applied Chemistry, 52, 11263$11265 . \quad \mathrm{https}: / / \mathrm{www} . e l i x i r$ publishers.com/articles/1398854304 _70\%20(2014)\%2023793-23798.

Abbas, M.N., Rana, S.A., Shadid M, Hassan, M.M. \& Husain, M. (2012). Chemical Evaluation of Weed Seeds Moxed With Wheat Grains At Harvest. The Journal of Animal and Plant Sciences, 22 (2), 283-288. http://www.thejaps.org. pk/docs/v22-2/08.pdf

Adesina, S.K., Idowu, O., Ogundaini, A.O., Oladimeji, H., Olugbade, T.A., Onawunmi, G.O., \& Pais, M. (2000). Antimicrobial Constituents of the Leaves of Acalypha wilkesiana and Acalypha hispida. Phytotherapy Research, 14 (8), 371374. http://doi.org/10.1002/ 10991573(200008)14:5<371::aidptr625>3.0.co;2-f

Aini, N.H., Saleh, C., \& Erwin. (2015). Uji Toksisitas dan Aktivitas Antibakteri Ekstrak Daun Merah Tanaman Pucuk Merah (Syzygium myrtifolium Walp.) Terhadap Bakteri Staphylococcus aureus dan Escherichia coli. Jurnal Kimia Mulawarman, 13 (1), 35-40. http://jurnal.kimia.fmipa.unmul.ac.id /index.php/JKM/article/view/43

Aini, N.P., Kalor, H., \& Atun, S. (2017). The antibacterial activity of Curcuma xanthorrhiza extract against Escherichia coli ATCC 11229 and Staphylococcus aureus ATCC 25923. Jurnal Penelitian
Saintek, 22 (2), 140-147. https://doi.org/10.21831/jps.v22i2.1 $\underline{7122}$.

Allison, D., \& Gilbert, P. (2004). Pharmaceutical Microbiology (7th ed). Blackwell Science Massachusets.

Bokshi, B., Sayeed, M.A.S., Ahmed, M.I., Karmakar, U.K., \& Sadhu, S.K. (2012). Assessment of antimicrobial and cytotoxic activities of ethanolic extract of leaves of Acalypha hispida. International Journal of Pharmaceutical Sciences and Research, 3(6), 1705-1708. http://dx.doi.org/10.13040/IJPSR.09 75-8232.3(6).1705-08.

Cowan, M.M. (1999). Plant Products as Antimicrobial Agents. Clinical Microbiology Reviews. 12 (4), 564582. $\quad$ https://doi.org/10.1128/ CMR.12.4.564

Harborne, J.B. (2006) Metode fitokimia penuntun cara modern menganalisis tumbuhan. Penerbit ITB, Bandung

Heriyati, Khotimah, S., Wardoyo, E.R.P. (2016). Aktivitas antibakteri fraksi diklorometan dan N-heksana paku sisik naga (Drymoglossum piloselloides (L) Presl.) terhadap bakteri Staphylococcus aureus dan Salmonella typhi. Protobiont, 5 (3), 82-88. http://jurnal.untan.ac.id/ index.php/jprb/article/view/17094/1 4601

Dalimartha, S. (2007). Atlas Tumbuhan Obat Indonesia Jilid 3. Puspa Swara, Jakarta.

Irene, E.R., \& Hatta, M. (2009) Deteksi mutasi gen gyrase a porphyromonas 
gingivalis resisten terhadap ciprofloxacin berdasarkan teknik polymerase chain reaction, Jurnal Kedokteran Yarsi, 17 (1), 11-20. http://academicjournal. ac.id/index.php/jurnal-fkyarsi/article/view/192/128

Kasenda, J.C., YamLean, P.V.Y., \& Lolo, W.A. (2016). Formulasi dan pengujian aktivitas antibakteri sabun cair ekstrak etanol daun ekor kucing (Acalypha hispida Burm.F) terhadap pertumbuhan bakteri Staphylococcus aureus. Jurnal Ilmiah Farmasi, 5 (3), 40-47. https://ejournal.unsrat.ac.id/index. php/pharmacon/article/view/12936/ 12523.

Kumoro, A.C. (2015) Teknologi Ekstraksi Senyawa Bahan Aktif dari Tanaman Obat. Plantaxia, Yogyakarta.

Manikanta, B., Varma, P.R., Krishna, P.V., Kumar, A.R., \& Rathina, K.M.S. (2014). Phytochemical and anti diarrhoeal activity of combined extracts of Acalypha hispida,Acalypha nervosa and Acalypha fruiticosa. Journal of Chemical and Pharmaceutical Sciences, 7 (3), 194-196. https://www.jchps.com/issues/Volu me\%207_Issue\%203/jchps\%207(3) \%204\%20bhargav2\%20197199.pdf

Moningka, K.S., Kojong, N.S., \& Sudewi, S. (2015) Uji aktivitas antibakteri ekstrak daun ekor kucing (Acalypha hispida Burm. F.) terhadap bakteri Staphylococcus aureus dan Escherichia coli secara in-vitro. Jurnal Ilmiah Farmasi, 4 (3), 193-
202. https://ejournal. unsrat.ac.id/index.php/pharmacon/ar $\underline{\text { ticle/view/8859/8417 }}$

Noumedem, J.A.K., Tamokou, J.D., Teke, G.N., Momo, R.C.D., Kuete, V., \& Kuiate, J.R. (2013). Phytochemical analysis, antimicrobial and radicalscavenging properties of Acalypha manniana leaves. SpringerPlus, 2 (503), 1-6. https://doi.org/10.1186/ 2193-1801-2-503

Prihatiningtyas, W., Mariani, Y., Oramahi, H.A., Yusro, F., \& Sisillia, L. (2018). Uji aktivitas antibakteri ekstrak etanol kulit batang mangga kweni (Mangifera odorata Griff) terhadap Escherichia coli ATCC 25922 DAN Staphylococcus aureus ATCC 25923. Jurnal Tengkawang. 8

59-74.

http://jurnal.untan.ac.id/

index.php/tengkawang/article/view/ $\underline{30206 / 75676579470}$

Roopashree, T.S., Dang, R., Rani, R.H.S. \& Narendra, C. (2008) Antibacterial activity of antipsoriatic herbs: Cassia tora, Mamordica charantia and Calendulla officinalis, International Journal of Applied Research in Natural Products, 1, 2028.

http://www.oalib.com/paper/258738 $\underline{1 \# . X q G A v \_k z b I U}$

Sugiyono. (2018). Metode Penelitian Kombinasi. Penerbit Alfabeta, Bandung.

Sutton, S. (2011). Measurement of microbial cells by optical density. Journal of Validation Technology, 17 46-47. https://www.ivtnetwork.com/article/ 
JURNAL TENGKAWANG (2020)

Vol. 10 (2): 97 - 108

measurement-microbial-cells-

optical-density

Syaifuddin, M.Q., Agus, M.K.B., Sukarsono \& Wahyuni, SH, 2018,

Efektivitas berbagai konsentrasi ekstrak daun kayu manis (Cinnamomum burmannii [Ness.] BI) terhadap diameter zona hambat pertumbuhan bakteri

Staphylococcus epidermidis, Jurnal Biota, $4 \quad$ (1), 12-18 http://jurnal.radenfatah.ac.id/index.p hp/biota/article/view/1454/pdf

Wardoyo, E.R.P., Nugroho, L. H., Santosa, Moeljopawiro, S. (2011). Efek sitotoksik ekstrak kloroform, methanol dan air buah Brucea javanica (L.) Merr. terhadap sel kanker payudara (T47D). Berkala Penelitian Hayati, 4D, (13-16). http://berkalahayati.org/files/journal s/1/articles/287/submission/287-

913-1-SM.pdf 